present it in the best possible light to critics within the scientific community we have tended to downplay some uncomfortable findings, especially the relative inefficacy of brief treatments for seriously disturbed patients, and the comparative success of supportive psychotherapy (as opposed to the formal model-based therapies with which most psychotherapists are identified) with these people. Perhaps we should learn from the finding that the relatively more fortunate (the "YAVIS" - young, attractive, verbal, intelligent, successful - patients) tend to do best in psychotherapy, and wonder if that is not because they generally do not suffer from social deprivation, so that, once psychological difficulties are overcome, an environment is available in which they can flourish. Perhaps we should place much greater emphasis on the need for simultaneous psychological and social care, if inequity and unhappiness in our society are to diminish. Perhaps we should argue much more strongly for long-term therapies if enduring change is to come about. Perhaps, finally, we should temper our enthusiasm with realism (as did Freud) and agree at least with one of Epstein's many cogent, if unmodulated, points that: "Therapy, especially in its weak form of some 10-15 hours of discussion with a therapist, may have greatly exaggerated the degree to which human behaviour is amenable to change."

JEREMY HOLMES North Devon District Hospital, Barnstaple

\section{Rethinking Life and Death. The Collapse of Our Traditional Ethics}

Peter Singer, Oxford, Oxford

University Press, 1995, 256 pages, £7.99.

In Rethinking Life and Death, Peter Singer invites practitioners to bring their moral thinking up to date with what they know and believe about the world and the position of men and women in it. This well-written book falls into three parts. The first two parts argue for a different understanding and definition of death by putting life into context. In the final part Singer abandons gentle persuasion and casts out the five threads which support the principle of the sanctity of life. In their place he proposes five new commandments (not this time to be written in stone) whereby issues of the prolongation and curtailment of life and death can be decided in terms of the quality of life.

Proceeding by reference to decided law cases, Singer tracks the changes in the medical definition of death. $\mathrm{He}$ makes no secret of the fact that medicine has had a vested interest in death being defined at a stage when vital organs are still warm and available for transplant. Brain stem death is earlier than the death of the whole body. In this book he argues that the failure of the cortex is a more logical time for death to be found. He accepts that emotionally, many doctors and health practitioners are not ready to come to this conclusion because some bodily functions can continue. Using our attitude to animals as an example, he points out the incoherence of this position. He charges us not with compassion but with inconsistency, which, he says, results from our attachment to inappropriate and old-fashioned ideas about the importance of human beings relative to other living things.

Medicine, law and society generally are so bound up in a religious and cultural account of the sanctity of an individual's life that decisions to terminate life or no longer to prolong life must be made in the interests of that individual. Doctors are forced to treat patients even though there is no possibility of cure, enjoyment or in some cases, consciousness. Other conclusions are not admissible. Singer cites the Tony Bland case as an example of a change in attitude. The court acknowledged that the continuance of treatment could bring no benefit to the patient or anybody else. Singer suggests that there is a discrepancy between what we believe ought to happen for the good of the patient and medical and legal conventions which embody the ethic of the sanctity of life. Singer believes that our moral beliefs have changed and that the quality of life is now much more important to us. He advocates that we should behave in a way which is consistent with this new ethic and finally discard the trappings of an outdated ethic. Holding on to it makes decisions about life and death impossible for both doctors and lawyers. The results are haphazard and inconsistent.

Singer, pushing us slightly further towards an ethic of quality of life, argues that death should be established when the cortex is ineffective rather than the brain stem. If this happened Singer states that there would be cases where a warm, pulsating body would be diagnosed as dead. Socially and culturally Singer realises that we are not ready to bury such bodies. At this point the first part ends. Singer has argued that sanctity of life is not a sensible guideline compared to the quality of life. He leaves us complacent in the thought that we cannot "kill" persons who are still breathing.

In the second part of the book, Singer gives examples of how easily doctors have been able to "kill" animals in order to experiment with putting their organs into humans. $\mathrm{He}$ argues that our belief that human beings are the only important animals on earth is a throwback to ancient times when it was thought that everything not only revolved around the earth but around humankind. Science and modern social knowledge have established that this is not the case. Genetically, humans are less different from a chimpanzee than a chimpanzee is from a gorilla. Singer argues that any logical definition of "person" could not include human beings without also including chimpanzees, baboons and many other animals.

By showing our willingness to kill animals and then equating animals to human beings, both being persons, Singer seeks to undermine the last vestiges of our resistance to quality of life being used as a marker for life and death.

He is ready now to put forward his five new commandments. Not so definite and clear cut as the old ones, they oblige moral agents to make coherent decisions and having made them to stick by them. Practitioners making decisions in Singer's Brave New World would have more flexibility and freedom to do what they think is in the patient's best interests. They would not be constrained by what Singer thinks are outdated principles, namely, the absolute sanctity of human life, total anthropocentricity and the relative disregard of the sanctity of all other life forms. More freedom, of course demands a much more rigorous examination of every case and having made a decision, each agent would be wholly morally responsible for its consequences. Singer's new ethic is not an easy one.

JANE PRITCHARD Centre for Professional Ethics, University of Central Lancashire 